\title{
Pengaruh Model Project Citizen dengan Pendekatan Saintifik Terhadap Penguasaan Kompetensi Kewarganegaraan dalam Pembelajaran Pendidikan Pancasila dan Kewarganegaraan
}

\author{
Galih Puji Mulyoto dan Samsuri
}

Program Pascasarjana Pendidikan Pancasila Dan Kewarganegaraan, Universitas Negeri Yogyakarta Jurusan PKnH FIS UNY / Prodi PPKn Program Pascasarjana UNY

newiota22@gmail.com

\begin{abstract}
This study was aimed at determining the effect of applying a project citizen model with the scientific approach in learning PPKn the mastery of civic competencies. This study uses a quantitative approach with a quasi-experimental research methods. Data collection technique were test, questionnaire and observation. Data were analyzed using $t$ test and Gain Score. The results showed that there is significant influence implementation of the project citizen model with the scientific approach to learning PPKn the mastery of civic competencies compared using problem-based learning model with a scientific approach. It is shown results posttest control group and experiment $t_{o} 7.182>2.000 t_{\text {tabel }}$. In every dimension of civic competencies also shows the results of a significant difference, namely: civic knowledge $\left(t_{o} 6.088>2.000 t_{\text {table }}\right)$, civic skills $\left(t_{o} 2,554>t_{\text {table }} 2.000\right)$, civic attitude $\left(t_{o} 2,055>t_{\text {table }} 2.000\right)$. Analysis Gain score in the experimental class showed 0.38 results in the category of "moderate", while the control group showed 0.15 results in the category of "low".
\end{abstract}

Keywords: Project citizen model, scientific approach, civic competences.

\section{Pendahuluan}

Paradigma

baru

Pendidikan

Kewarganegaraan di Indonesia sekarang ini telah menekankan pada peran dalam membentuk warga negara yang cerdas dan baik. Peran tersebut tidak hanya membentuk warga negara hanya mengetahui hak dan kewajibannya, tetapi juga memahami tanggung jawab serta partisipasi/keterlibatan warga negara dalam setiap kebijakan publik. Dalam hal ini, terdapat kompetensikompetensi yang harus diajarkan dan dimiliki setiap warga negara atau biasa disebut sebagai kompetensi kewarganegaraan dalam kehidupan sehari-hari.

Kompetensi ini, menurut Audigier (Audigier, 2000, p. 17) mengacu pada pengetahuan, sikap, nilai-nilai dan keterampilan yang diperlukan untuk berpartisipasi dalam kehidupan warga negara, serta mampu memainkan peran warga negara dan yang memungkinkan seseorang untuk menjadi warga yang aktif. Sedangkan, Print (2013, pp. 38-39) memberikan definisi kompetensi kewarganegaraan sebagai suatu kemampuan, potensi dan kemauan untuk terlibat dalam fenomena. Hal ini mengacu pada kombinasi kompleks pengetahuan, keterampilan, pemahaman, nilai-nilai, sikap dan keinginan yang menyebabkan efektif, dan diwujudkan dalam tindakan pada domain tertentu.

Di sisi lain, kompetensi kewarganegaraan ini menunjukkan perspektif dari Pendidikan Kewarganegaraan yang merupakan dasar ide-ide, konsep, prinsip, keterampilan, dan kualitas afektif dalam Kurikulum (Doğanay, 2012, p. 31). Hal yang sama dikemukakan Patrick \& Vontz (2001) bahwa dasar untuk kompetensi kewarganegaraan terletak pada pengembangan pengetahuan, keterampilan, dan disposisi yang berkaitan dengan konsep inti tentang prinsip-prinsip dan praktik- 
praktik kewarganegaraan dalam demokrasi. Oleh karena itu, pengetahuan, keterampilan, nilai dan sikap harus dimasukkan dalam Kurikulum pendidikan kewarganegaraan tidak terpisah, tetapi terintegrasi dalam Kurikulum (Doğanay, 2012, p. 36). Meskipun, Reid (1986) (dalam Doğanay, 2012, p. 36) menjelaskan bahwa pengetahuan, sikap dan keterampilan dibedakan secara konseptual, namun kompetensi tersebut tidak dapat dipisahkan eksistensial, sehingga tidak mungkin untuk pengetahuan terpisah dari keterampilan atau sikap dalam proses pembelajaran PKn.

Realitanya, di Indonesia pembelajaran PKn yang menekankan tentang penguasaan kompetensi kewarganegaraan masih terjadi ketimpangan, baik dalam struktur Kurikulum maupun dalam pembelajaran di kelas. Temuan beberapa hasil penelitian dalam pembelajaran PKn menunjukkan hal tersebut. Hasil kajian dari Pusat Kurikulum (Puskur) Balitbang Depdiknas, terhadap Kurikulum Satuan Tingkat Pendidikan (KTSP), menunjukkan bahwa mata pelajaran PKn hanya memuat $12 \% \mathrm{KD}$ aspek civic disposition dan $20,17 \%$ aspek civic skill/participation, sedangkan yang memuat aspek civic knowledge 69,43 \%. Menurut Puskur berarti susunan ini tidak konsisten dengan misi Pendidikan Kewarganegaraan yang bertujuan untuk membentuk watak warga negara yang (Pusat Kurikulum Balitbang Depdiknas, 2007, pp. 21-22). Hasil pra penelitian di SMPN 5 Kota Yogyakarta, pada tanggal 14 September 2015 menunjukkan hasil yang hampir sama. Dalam hal ini, pembelajaran PPKn di SMPN 5 Yogyakarta yang telah menggunakan Kurikulum 2013, lebih dominan pada aspek pengetahuan siswa, sehingga siswa kurang untuk mengembangkan aspek keterampilan dan sikap. Selanjutnya, guru mengalami kesulitan dalam menerapkan pembelajaran PPKn menggunakan pendekatan saintifik yang dapat mengembangkan penguasaan kompetensi kewarganegaraan secara seimbang dalam pembelajaran PPKn.

Hasil penelitian ICCS (Fraillon, Schulz, \& Ainley, 2012) terhadap Pendidikan Kewarganegaraan di lima negara (Indonesia, Hong Kong, Republik Korea/Korea Selatan, Taiwan, dan Thailand) menunjukkan bahwa tes pengetahuan kewarganegaraan siswa sekolah menengah di Indonesia dan Thailand lebih rendah jika dibandingkan dengan negara sampel lainnya di Asia. Hal ini menunjukkan meskipun aspek pengetahuan kewarganegaraan lebih banyak diajarkan di kelas, namun tidak menjamin pengetahuan kewarganegaraan siswa lebih tinggi. Oleh karena itu, dalam penerapan kompetensi kewarganegaraan harus seimbang baik dari aspek kompetensi pengetahuan, sikap maupun keterampilan, sehingga akan dapat membentuk warga negara yang baik.

Fakta-fakta tersebut menunjukkan Pendidikan Pancasila dan Kewarganegaraan di Indonesia masih dalam tataran Pendidikan Kewarganegaraan minimalis. Menurut Kerr (1999, p. 14) ke dalam Pendidikan Kewarganegaraan minimalis didefinisikan secara sempit, hanya mewadahi aspirasi tertentu, berbentuk civic education, bersifat formal, terikat oleh isi, berorientasi pada pengetahuan, menitikberatkan pada proses pengajaran, dan hasilnya mudah diukur. Dengan demikian, dibutuhkan inovasi dalam pembelajaran Pendidikan Pancasila dan Kewarganegaraan untuk mengubah dari Pendidikan Kewarganegaraan yang minimalis menuju Pendidikan Kewarganegaraan yang maksimal. Selain itu, perumusan mata pelajaran PPKn diharapkan 
mengembangkan

kompetensi

kewarganegaraan, yang tidak hanya terfokus pada aspek pengetahuan, namun juga pada aspek keterampilan dan sikap.

Berkaitan dengan kompetensi kewarganegaraan, Print \& Lange (2012, p. 39) mengemukakan bahwa istilah kompetensi kewarganegaraan mengacu pada pengetahuan, sikap, nilai-nilai, dan keterampilan yang diperlukan untuk partisipasi dalam kehidupan sipil dan politik, sehingga hal tersebut mampu memainkan peran warga negara menjadi warga aktif. Dalam hal ini, pendapat yang sama diungkapkan beberapa para ahli bahwa ruang lingkup Kurikulum Pendidikan Kewarganegaraan harus didasarkan pada tiga dimensi utama. Dimensi pertama, yaitu pengetahuan berisi sub kategori yang terdiri dari politik, sosial, budaya, ekonomi dan bentuk partisipasi. Dimensi kedua yang meliputi daerah afektif terdiri dari subkategori yaitu nilai-nilai, sikap dan disposisi. Dimensi terakhir yaitu keterampilan terdiri dari dua sub-kategori yaitu keterampilan umum dan kemampuan partisipasi (Doğanay, 2012, p. 31). Oleh karena itu, dibutuhkan pembelajaran yang mampu mengembangkan kompetensi kewarganegaraan siswa. Salah satunya menggunakan praktik kewarganegaraan.

Pembelajaran menggunakan praktik kewarganegaraan akan mampu meningkatkan tingkat partisipasi siswa dan keaktifan siswa di kelas. Dalam hal ini, dikarenakan proses pembelajaran praktik kewarganegaraan mengajarkan siswa pembelajaran yang langsung berkaitan dengan konteks kehidupan sehari-hari. Sepaham dengan hal tersebut, Kintisch \& Cordero (1993) mengemukakan bahwa siswa belajar lebih aktif, ketika dimasukkan ke dalam situasi yang mengharuskan mereka untuk melakukan penilaian suatu masalah publik dibandingkan dengan hanya mengingat informasi.

Sementara itu, pendapat dari beberapa ahli seperti Cogan (1998), (1999, p. 2), Doganay (2012), dan Print dan Lange (2012) menunjukkan tujuan dari proses pembelajaran Pendidikan Kewarganegaraan adalah untuk menyiapkan generasi muda (siswa) menjadi warga negara yang memiliki pengetahuan, kecakapan dan nilai-nilai yang diperlukan untuk berperan serta (partisipasi) aktif dalam masyarakat. Jika warga negara sudah tercermin dalam aspek-aspek tersebut maka tujuan PPKn sudah dapat dikatakan berhasil. Meskipun, dibutuhkan peran dan dukungan berbagai pihak untuk mewujudkan tujuan tersebut. Salah satunya model pembelajaran yang mampu mengembangkan kompetensi kewarganegaraan siswa adalah menggunakan model Project Citizen.

Para ahli seperti Vontz, Metcalf, \& Patrick (2000), Tolo (1998), Haas (2001), Vontz \& Nixon (1999) dan Craddock, Fischer \& Subreenduth (2007), sepakat mengungkapkan bahwa model Project Citizen adalah model pembelajaran berbasis isu-isu masyarakat yang berkaitan dengan kebijakan publik. Model Project Citizen akan membantu siswa bukan hanya untuk memahami konsep dan prinsip keilmuan, tetapi juga mengembangkan kemampuannya untuk bekerja secara kooperatif melalui kegiatan belajar praktik empirik dalam kelas. Model Project Citizen, menurut Vontz \& Patrick (2001, p. 6) akan memberikan siswa kesempatan untuk berpartisipasi dalam pemerintahan dan masyarakat dengan cara berlatih berpikir kritis, dialog, debat, negosiasi, kerja sama, kesopanan, toleransi, pengambilan keputusan, dan tindakan sipil untuk kebaikan bersama. Oleh karena itu, 
pembelajaran Pendidikan Kewarganegaraan akan semakin menantang, mengaktifkan dan lebih bermakna.

Pada dasarnya pembelajaran model Project Citizen lebih menonjolkan kepada strategi upaya memahamkan siswa dengan dasar-dasar pengetahuan, bagaimana warga negara harus mengambil tanggung jawab kewarganegaraan (Samsuri, 2011, p. 4). Model Project Citizen strategi pembelajaran yang dilakukan ialah bagaimana siswa mengambil peran aktif dalam ruang kelas dengan berkolaborasi dalam pembelajaran. Berdasarkan buku Project citizen ... A We the People Portfolio-Based Program, yang disusun oleh Center for Civic Education, model Project Citizen memiliki langkahlangkah sebagai berikut 1) Mengidentifikasi masalah kebijakan publik yang ada dalam masyarakat, 2) Pemilihan masalah sebagai fokus kajian kelas, 3) Pengumpulan informasi terkait masalah yang menjadi fokus kajian kelas, 4) Pengembangan suatu portofolio kelas, 5) Penyajian portofolio (show case), 6) Refleksi atas pengalaman belajar yang dilakukan (Center for Civic Education, 2006).

Keberhasilan pelaksanaan pembelajaran praktik kewarganegaraan dalam pembelajaran PKn ini, didukung oleh beberapa hasil penelitian, antara lain hasil penelitian yang dilakukan oleh Patrick \& Vontz (2001), Vontz, Metcalf, \& Patrick (2000), Tolo (1998), Haas (2001), Liou (2004), Vontz \& Nixon (1999), dan Craddock, Fischer \& Subreenduth (2007) di beberapa negara berkaitan tentang model Project Citizen menyimpulkan bahwa model ini mampu mengembangkan pengetahuan kewarganegaraan (civic knowledge), keterampilan kewarganegaraan (civic skill), dan watak kewarganegaraan (civic disposition). Kekuatan Project Citizen adalah transfer keterampilan pengetahuan, dan sikap dicapai melalui strategi pembelajaran aktif (Joyce, Weil, \& Calhoun, 2000).

Upaya kedua dalam mengembangkan kompetensi kewarganegaraan kepada siswa dalam pembelajaran PKn adalah dengan menerapkan pendekatan dalam pembelajaran. Sejalan dengan perubahan Kurikulum pendidikan di Indonesia saat ini, Kurikulum 2013 yang tengah berjalan di beberapa sekolah berorientasi pada sebuah pendekatan yang disebut pendekatan saintifik. Meskipun, perkembangannya terjadi berbagai polemik terhadap penerapan Kurikulum 2013 di berbagai wilayah di Indonesia. Pemerintah memutuskan untuk mengkaji ulang pelaksanaan Kurikulum 2013 karena di nilai belum siap dilaksanakan. Padahal, Kurikulum 2013 sudah diujicobakan lebih dari 6.221 sekolah sejak tahun ajaran 2014/2015 dan dilaksanakan secara menyeluruh pada tahun pelajaran 2014/2015 di lebih dari 208 ribu satuan (Alawiyah, 2015, p. 9).

Dampaknya, Pendidikan Pancasila dan Kewarganegaraan dalam Kurikulum ikut mengalami berbagai nomenklatur yang berubah-ubah. Pada Kurikulum 2006 dengan Pendidikan Kewarganegaraan, sedangkan Kurikulum 2013 dengan Pendidikan Pancasila dan Kewarganegaraan. Selanjutnya, Kompetensi Inti dan Kompetensi Dasar mata pelajaran Pendidikan Pancasila dan Kewarganegaraan pada Kurikulum 2013, mengikuti Himmelmann (2013) mengubah paradigma Pendidikan Pancasila dan Kewarganegaraan yang semula berfokus kepada program pengajaran dan transfer pengetahuan kewarganegaraan menjadi pendekatan yang menekankan sikapsikap personal-individual, moral dan perilaku sosial sebagaimana disposisi dan nilai-nilai bersama dari warga negara. Oleh karena itu, 
penerapan pendekatan saintifik harapannya akan dapat merubah paradigma PPKn yang selama ini hanya berpusat pada pengetahuan saja, namun secara lengkap mencangkup kompetensi kewarganegaraan yang utuh dan seimbang.

Kurikulum 2013, dalam modul Pendekatan dan Strategi Pembelajaran dijelaskan bahwa konsep dasar pendekatan saintifik yang merupakan pendekatan dalam mengimplementasikan Kurikulum 2013, didefinisikan sebagai proses pembelajaran yang dirancang sedemikian rupa agar peserta didik secara aktif mengkonstruk konsep, hukum atau prinsip melalui tahapan-tahapan mengamati (untuk mengidentifikasi atau menemukan masalah), merumuskan masalah, mengajukan atau merumuskan hipotesis, mengumpulkan data dengan berbagai teknik, menganalisis data, menarik kesimpulan dan mengomunikasikan konsep, hukum atau prinsip yang "ditemukan".

Pembelajaran dengan pendekatan saintifik melalui konsepsi $5 \mathrm{M}$ (mengamati, menanya, menalar, mencoba, menyimpulkan dan mengomunikasikan) memungkinkan perubahan paradigma pembelajaran Pendidikan Pancasila dan Kewarganegaraan dari pembelajaran pasif dan afirmatif kepada pembelajaran aktif, kooperatif, dan kritis (Samsuri, 2013, p. 6).

Berdasarkan identifikasi masalah, maka rumusan masalah penelitian ini adalah, adakah pengaruh pembelajaran PPKn menggunakan model Project Citizen dengan pendekatan saintifik terhadap penguasaan kompetensi kewarganegaraan siswa kelas 8 di SMP Negeri 5 Yogyakarta? Selanjutnya, tujuan penelitian ini adalah untuk mengetahui pengaruh pembelajaran PPKn menggunakan model Project Citizen dengan pendekatan saintifik terhadap penguasaan kompetensi kewarganegaraan siswa kelas 8 di SMP Negeri 5 Yogyakarta.

\section{Metode}

Penelitian ini menggunakan pendekatan kuantitatif dengan metode penelitian eksperimen semu. Eksperimen dilakukan terhadap pembelajaran PPKn menggunakan model Project Citizen dengan pendekatan saintifik, sedangkan untuk kontrol pembelajaran PPKn menggunakan model pembelajaran berbasis masalah. Hal ini dimaksudkan untuk mengetahui perbedaan penguasaan kompetensi kewarganegaraan, dengan materi Hak Asasi Manusia.

Penelitian ini dilaksanakan pada 13 Januari 2016 sampai dengan 28 Februari 2016. Penelitian dilaksanakan di SMP Negeri 5 Yogyakarta. Populasi pada penelitian ini adalah siswa kelas VIII di SMP Negeri 5 Yogyakarta. Pengambilan sampel dari penelitian ini dilakukan secara simple random sampling karena populasi penelitian dianggap homogen. Penelitian ini menggunakan dua kelas, yaitu kelas VIII.2 sebagai kelas eksperimen yang menggunakan model Project Citizen dengan pendekatan saintifik, dan VIII.3 sebagai kelas kontrol, dengan model pembelajaran berbasis masalah pendekatan saintifik. Kelas eksperimen terdiri dari 34 siswa, dan kelas kontrol terdiri dari 34 peserta didik. Sebelum penelitian eksperimen ini dilakukan terlebih dahulu diadakan pretest, baik pada satu kelas eksperimen (perlakuan) maupun satu kelas kontrol untuk mengetahui kemampuan awal peserta didik. Kelas eksperimen diterapkan pembelajaran dengan menggunakan model Project Citizen dengan pendekatan saintifik. Kelompok pada kelas kontrol diterapkan pembelajaran dengan menggunakan model PBM dengan pendekatan saintifik. 
Teknik pengumpulan data yang digunakan pada penelitian ini disesuaikan dengan teknik instrumen penilaian pada Kurikulum 2013. Teknik dan instrumen pengumpulan data digunakan untuk mengukur kompetensi kewarganegaraan (civic competence). Instrument yang digunakan adalah tes, angket, dan observasi. Tes aspek pengetahuan menggunakan bentuk pilihan ganda.

Angket adalah untuk mengetahui penguasaan kompetensi sikap dan keterampilan intelektual siswa dalam pembelajaran PPKn berkaitan tentang penegakan dan perlindungan hak asasi manusia dalam kehidupan sehari-hari. Pada instrumen angket untuk mengukur sikap terdapat 20 butir pernyataan, sedangkan angket untuk mengukur keterampilan terdapat 5 butir pernyataan. Alat ukur yang digunakan untuk angket variabel keterampilan dan angket variabel sikap dengan skala Likert, 1 sampai dengan 4. Skala $4=$ selalu, skala $3=$ sering, skala 2 = kadang-kadang, skala $1=$ tidak pernah. Bentuk angket variabel keterampilan dan angket variabel sikap dengan menggunakan checklist.

Teknik observasi untuk mengetahui pelaksanaan model Project Citizen dengan pendekatan saintifik dan mengetahui keterampilan partisipasi siswa. Instrumen yang digunakan adalah lembar observasi. Skala alat ukur lembar observasi model Project Citizen dengan pendekatan saintifik menggunakan skala Guttman (benar skor 1 dan salah skor 0), dengan bentuk checklist. Sementara instrumen lembar observasi keterampilan partisipasi siswa menggunakan skala Likert, dengan item 1 sampai 5 (1: tidak tepat, 2: kurang tepat, 3: cukup tepat, 4: tepat, 5: sangat tepat). Bentuk instrumen lembar observasi kompetensi keterampilan partisipasi siswa adalah checklist..

Sebelum melakukan penelitian, terlebih dahulu instrumen dilakukan validasi. Validitas sendiri dibagi menjadi 2 yang pertama, validitas ahli yakni proses validitas dengan meminta pertimbangan ahli untuk menilai item-item instrumen apakah sudah sesuai atau belum. Kedua, Validitas dengan melakukan uji coba dilakukan pada siswa kelas VIII SMP Negeri 8 Yogyakarta dengan jumlah 30 responden. Uji validitas menggunakan rumus product moment dari Pearson, di peroleh hasil 1) angket sikap dari jumlah 22 item, terdapat 2 item pernyataan yang gugur yaitu nomor 21 ( $\mathrm{r}$ hitung $=0,279$ ) dan 22 ( $\mathrm{r}$ hitung $=0.118$ ), dan 20 butir pernyataan valid karena $r$ hitung $>$ dari $r$ tabel. 2) angket keterampilan intelektual terdapat 5 item pernyataan dinyatakan valid. Hal ini dikarenakan $\mathrm{r}$ hitung > dari $\mathrm{r}$ tabel pada instrumen keterampilan. 3) tes pilihan ganda dari jumlah 33 item pernyataan yang gugur yaitu nomor 31 ( $\mathrm{r}$ hitung $=0.180$ ), 32 ( $\mathrm{r}$ hitung $=0.056)$, dan 33 ( $\mathrm{r}$ hitung $=0.101)$. Sedangkan 30 item dinyatakan valid dikarenakan $r$ hitung $>$ dari $r$ tabel.

Setelah melakukan uji validitas maka dilanjutkan dengan, uji reliabilitas. Uji ini dilakukan untuk mengukur kepercayaan terhadap alat tes. Syarat keandalan terhadap suatu instrumen menuntut kemantapan, kestabilan, antara hasil pengamatan dengan instrument. Dalam penelitian ini, untuk menguji reliabilitas instrumen digunakan metode alpha. Instrumen dikatakan reliabel jika $\alpha>0,600$, jika $\alpha<0,600$, maka instrumen tidak reliabel. Analisis penelitian ini dengan menggunakan bantuan program komputer SPSS Versi 21.0 for windows. Berikut hasil angket kompetensi sikap adalah $\mathrm{r}$ hitung 0,894 , artinya $r$ hitung $>r$ tabel maka dapat 
dikatakan instrumen tersebut reliabel dengan kategori tinggi. Pada angket kompetensi keterampilan adalah $r$ hitung 0,740, artinya $r$ hitung > $\mathrm{r}$ tabel maka dapat dikatakan instrumen tersebut reliabel dengan kategori cukup. Pada pilihan ganda kompetensi pengetahuan adalah $r$ hitung 0,914 , artinya $r$ hitung > $\mathrm{r}$ tabel maka dapat dikatakan instrumen tersebut reliabel dengan kategori tinggi.

Tahap selanjutnya adalah analisis butir soal pada instrumen tes pilihan ganda. Pada tahap ini ada dua langkah yang dilakukan, yaitu analisis tingkat kesukaran butir soal dan daya beda. Berdasarkan hasil analisis tingkat kesukaran butir soal diperoleh hasil pada tabel 1.

Tabel 1 Hasil Analisis Tingkat Kesukaran Butir Soal

\begin{tabular}{lcl}
\hline Kategori & $\begin{array}{c}\text { Jumlah } \\
\text { item }\end{array}$ & \multicolumn{1}{c}{ No. Soal } \\
\hline Mudah & 16 & $\begin{array}{l}1,2,3,6,12,13,14,16,1 \\
8,19,22,23,25,27,28, \\
\text { dan } 29\end{array}$ \\
& & $\begin{array}{l}4,5,7,8,9,10,11,15,17, \\
20,21,24, \text { dan } 26\end{array}$ \\
Sedang & 14 & 31,32, dan 33 \\
Sukar & 3 & \\
\hline
\end{tabular}

Sumber: data hasil penelitian, 2016.

Sedangkan, hasil daya beda menunjukkan data pada tabel 2 .

Tabel 2 Hasil daya beda

\begin{tabular}{|c|c|c|}
\hline Kategori & $\begin{array}{c}\text { Jumlah } \\
\text { item }\end{array}$ & No. Soal \\
\hline $\begin{array}{l}\text { Soal diterima } \\
\text { baik }\end{array}$ & 25 & $\begin{array}{l}1,2,4,5,7,8,9,10,13 \\
, 16,17,18,19,29,21 \\
, 22,23,24,25,26,27 \\
28,29 \text { dan } 30\end{array}$ \\
\hline $\begin{array}{l}\text { Soal diterima } \\
\text { dengan revisi }\end{array}$ & 4 & $3,6,14$, dan 15 \\
\hline Soal direvisi & 1 & 12 \\
\hline Soal dibuang & 3 & 31,32 , dan 33 \\
\hline
\end{tabular}

Sumber: data hasil penelitian, 2016.

Setelah instrumen dinyatakan valid dan reliabel maka instrumen tersebut dapat digunakan untuk mengumpulkan data, yang selanjutnya akan dilakukan analisis. Dalam proses analisisnya yang pertama dilakukan uji Prasyarat Analisis Data. Pertama, uji normalitas yang menguji apakah dalam suatu model regresi variabel dependent, variabel independent ataukah keduanya berdistribusi normal. Kedua, uji homogenitas digunakan untuk mengetahui kesamaan varian antara kelas eksperimen dan kelas kontrol.

Setelah data terbukti memenuhi prasyarat distribusi normal dan varians antar kelompok homogen, maka tahap analisis data selanjutnya adalah pengujian hipotesis. Pengujian dilakukan dengan menggunakan uji t dan gain score. Uji beda t- test digunakan untuk mengetahui apakah dua sampel yang tidak berhubungan memiliki rata- rata yang berbeda. Uji beda t-test ini dilakukan dengan cara membandingkan antara dua nilai ratarata dengan standar error dari perbedaan dua sampel. Pengujian hipotesis untuk mengetahui perbedaan penguasaan kompetensi kewarganegaraan siswa antara kelas eksperimen dan kelas kontrol. Sementara uji Gain Score untuk mengetahui pengaruh penguasaan kompetensi kewarganegaraan siswa kelas eksperimen dan kelas kontrol.

\section{Hasil dan Pembahasan}

Hasil penelitian dibagi menjadi dua macam data, yaitu data skor pretest dan posttest. Data diperoleh dari masing-masing kelas sebelum diberikan perlakuan dan sesudah diberikan perlakuan. Dalam hal ini kelas eksperimen diberikan perlakuan dengan menggunakan model Project Citizen dengan pendekatan saintifik, sedangkan kelas kontrol dengan menggunakan model pembelajaran berbasis masalah dengan pendekatan saintifik.

Kategorisasi pretest kelompok eksperimen menunjukkan penguasaan kompetensi kewarganegaraan adalah 100\% 
dalam kategori baik. Berikut diagram kategorisasi pretest kelompok eksperimen dalam penguasaan kompetensi kewarganegaraan.

Gambar Kategorisasi Pretest Kelompok Eksperimen dalam Penguasaan Kompetensi

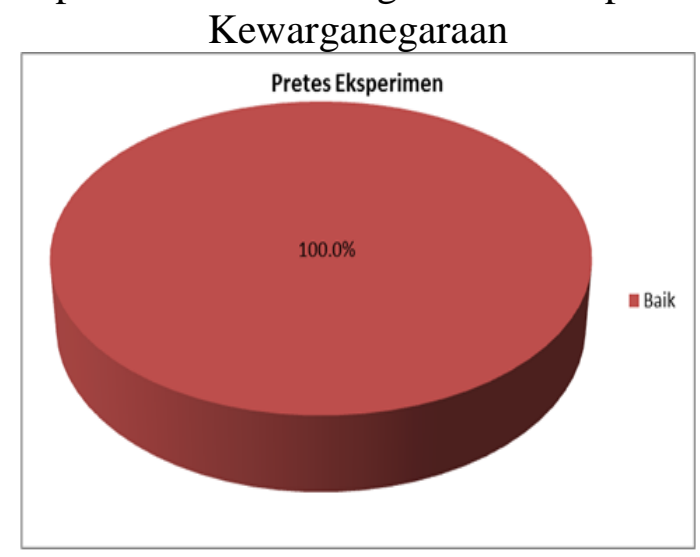

Sumber: data hasil penelitian, 2016

Kategorisasi posttest kelompok eksperimen dalam penguasaan kompetensi kewarganegaraan adalah sangat baik sebanyak 24 siswa atau 70,6\%, dan kategori baik sebanyak 10 siswa atau $29,4 \%$. Berikut diagram kategorisasi pretest kelompok eksperimen dalam penguasaan kompetensi kewarganegaraan.

Gambar 2 Kategorisasi Posttest Kelompok Eksperimen dalam Penguasaan Kompetensi

Kewarganegaraan

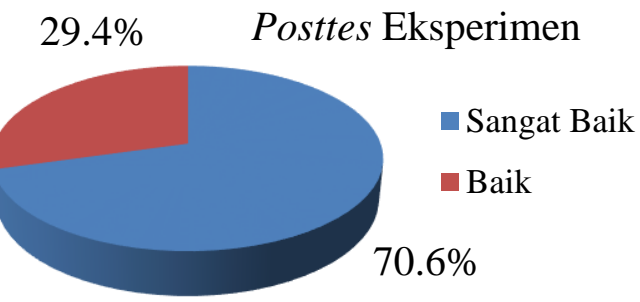

Sumber: data hasil penelitian, 2016

Kategorisasi pretest pada kelompok kontrol terhadap penguasaan kompetensi kewarganegaraan adalah kategori sangat baik sebanyak 1 siswa atau 2,9\% dan kategori baik sebanyak 33 siswa atau 97,1\%. Berikut diagram kategorisasi pretest kelompok kontrol dalam penguasaan kompetensi kewarganegaraan.

Gambar 3 Kategorisasi Pretest Kelompok Kontrol Dalam Penguasaan Kompetensi Kewarganegaraan

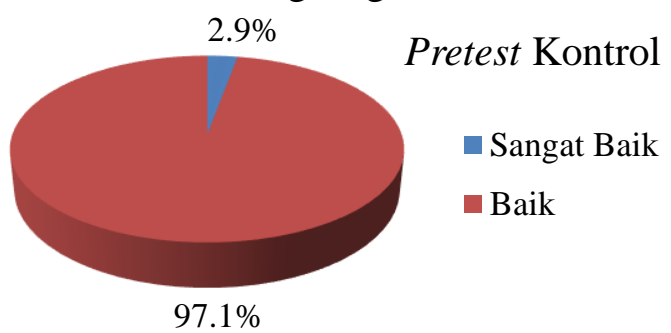

Sumber: data hasil penelitian, 2016

Kategorisasi posttest kelompok kontrol dalam penguasaan kompetensi kewarganegaraan dengan kategori sangat baik sebanyak 2 siswa dan kategori baik sebanyak 32 siswa. Berikut diagram kategorisasi posttest kelompok kontrol dalam penguasaan kompetensi kewarganegaraan.

Gambar 4 Kategorisasi Posttest Kelompok Kontrol dalam Penguasaan Kompetensi Kewarganegaraan

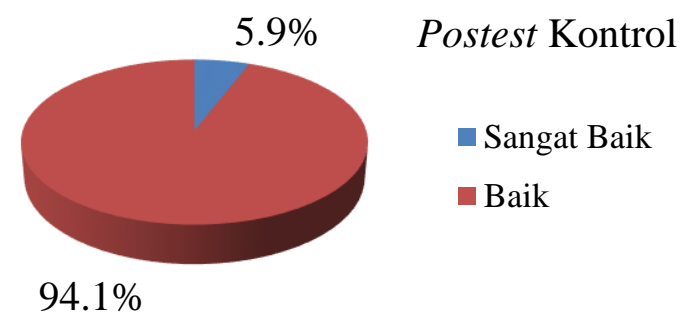

Sumber: data hasil penelitian, 2016

Sebelum menguji hipotesis dilakukan uji persyaratan analisis, yakni uji normalitas dan uji homogenitas.

Berikut disajikan tabel 3 hasil perhitungan uji normalitas skor pretest dan posttest kelompok kontrol dan eksperimen tes penguasaan kompetensi kewarganegaraan.

Tabel 3 Hasil Uji Normalitas Sebaran Data Tes Penguasaan Kompetensi Kewarganegaraan 


\begin{tabular}{lcc}
\hline \multicolumn{1}{c}{ Data } & Sig. & $\begin{array}{c}\text { Keteranga } \\
\text { n }\end{array}$ \\
\hline $\begin{array}{l}\text { Pretest Kelompok } \\
\text { Kontrol }\end{array}$ & 0,999 & $>0,05=$ \\
Pretest Kelompok & 0,467 & normal \\
Eksperimen & & normal \\
Posttest Kelompok & 0,771 & $>0,05=$ \\
Kontrol & & normal \\
Posttest Kelompok & 0,856 & $>0,05=$ \\
Eksperimen & & normal \\
\hline
\end{tabular}

Sumber: data hasil penelitian, 2016.

Berdasarkan hasil perhitungan pada tabel 3 dapat diketahui bahwa sebaran data normal, karena mempunyai nilai signifikansi lebih besar dari 0,05 pada ( $p>0,05)$. Jadi, data ini telah memenuhi syarat untuk dianalisis.

Tahap selanjutnya setelah uji normalitas adalah uji homogenitas varians. Uji ini dimaksudkan untuk mengetahui sampel berasal dari populasi yang memiliki varians yang sama. Adapun ringkasan hasil uji homogenitas varian data disajikan dalam tabel 4.

Tabel 4 Ringkasan Uji Homogenitas

\begin{tabular}{lcc}
\hline \multicolumn{1}{c}{ Data } & Sig. & Keterangan \\
\hline $\begin{array}{l}\text { Penguasaaan } \\
\text { Kompetensi }\end{array}$ & 0,586 & Homogen \\
$\begin{array}{l}\text { Kewarganegaraan } \\
\text { Pengetahuan }\end{array}$ & 0,054 & Homogen \\
$\begin{array}{l}\text { Kewarganegaraan } \\
\text { Keterampilan }\end{array}$ & & \\
$\begin{array}{l}\text { Kewarganegaraan: } \\
\text { keterampilan }\end{array}$ & 0,775 & Homogen \\
$\begin{array}{l}\text { Intelektual } \\
\text { keterampilan } \\
\text { partisipasi }\end{array}$ & 0,385 & Homogen \\
$\begin{array}{l}\text { Sikap } \\
\text { Kewarganegaraan }\end{array}$ & 0,535 & Homogen \\
\hline
\end{tabular}

Sumber: data hasil penelitian, 2016.

Hasil perhitungan uji homogenitas pada tabel 4. menunjukkan bahwa data tersebut mempunyai varians yang homogen, karena nilai signifikansi lebih besar dari 5\% ( $\mathrm{p}>0,05)$ Jadi, data tersebut telah memenuhi syarat untuk dianalisis.

Uji hipotesis menggunakan analisis uji $\mathrm{t}$ dan Gain Score. Analisis dengan uji-t dilakukan untuk mengetahui perbedaan penguasaaan kompetensi kewarganegaraan sebelum diberikan perlakuan pada kelompok kontrol dan kelompok eksperimen. Hasil rangkuman analisis data pretest penguasaaan kompetensi kewarganegaraan kelompok kontrol dan eksperimen dapat dilihat pada tabel 5 .

Tabel 5 Hasil Uji-T Skor Pretest Kelompok Eksperimen dan Kelompok Kontrol

\begin{tabular}{cccccc}
\hline $\mathbf{N}$ & $\mathbf{t}_{\mathbf{o}}$ & $\mathbf{t}_{\text {table }}$ & df & $\begin{array}{c}\text { Nilai } \\
\mathbf{P}\end{array}$ & Sig. \\
\hline 34 & 0,950 & 2,000 & 66 & 0,346 & 0,05 \\
\hline \multicolumn{5}{c}{ Sumber: data hasil penelitian, 2016}
\end{tabular}

Tabel 5 menunjukkan hasil bahwa tidak ada perbedaan yang signifikan tes awal penguasaan kompetensi kewarganegaraan siswa antara kelompok kontrol dan kelompok eksperimen. Hal ini ditunjukkan hasil to 0,950 lebih kecil daripada $t_{\text {tabel }} 2,000$. Pada setiap dimensi kompetensi kewarganegaraan juga menunjukkan hasil sama. Berikut penjabaran setiap dimensi kompetensi kewarganegaraan tabel 6.

Tabel 6 Rangkuman Hasil Uji-T Pretest Setiap Dimensi Kompetensi

Kewarganegaraan Kelompok Eksperimen dan Kelompok Kontrol

\begin{tabular}{ccccccc}
\hline Data & $\mathbf{N}$ & $\mathbf{t}_{\mathbf{~}}$ & $\mathbf{t}_{\text {tabel }}$ & $\mathbf{d f}$ & Sig. & Ket. \\
\hline CK & 34 & 1,282 & 2,000 & 66 & 0,204 & $>0,05$ \\
CS & 34 & 1,885 & 2,000 & 66 & 0,64 & $>0,05$ \\
CD & 34 & 1,728 & 2,000 & 66 & 0,089 & $>0,05$ \\
\hline \multicolumn{7}{c}{ Ket.: CK= Civic Knowladge, CS= Civic Skills, CD $=$ Civic } \\
\multicolumn{7}{c}{ Disposition }
\end{tabular}

Sumber: data hasil penelitian, 2016

Pada tabel 6 menunjukkan hasil bahwa tidak ada perbedaan yang signifikan tes awal pengetahuan kewarganegaraan siswa antara kelompok kontrol dan kelompok eksperimen. Hal ini ditunjukkan $t_{o}$ 1,282 lebih kecil daripada $t_{\text {tabel }}$ 2,000. Pada keterampilan kewarganegaraan siswa antara kelompok kontrol dan kelompok eksperimen menunjukkan hasil tidak ada perbedaan. Hal 
ini ditunjukkan $t_{\mathrm{o}}$ 1,885 lebih kecil daripada $t_{\text {tabel 2,000. Pada tes awal sikap }}$ kewarganegaraan siswa antara kelompok kontrol kelompok eksperimen menunjukkan tidak ada perbedaan. Hal ini ditunjukkan hasil $t_{0}$ 0,950 lebih kecil daripada $t_{\text {tabel }} 2,000$.

Berdasarkan berbagai hasil analisis di atas dapat disimpulkan bahwa tes kemampuan awal penguasaan kompetensi kewarganegaraan dalam pembelajaran PPKn kelompok yang menggunakan model Project citizen dengan pendekatan saintifik menunjukkan tidak ada perbedaan dibandingkan kelompok yang menggunakan model pembelajaran berbasis masalah dengan pendekatan saintifik. Tahap selanjutnya, dilakukan uji-t untuk melihat kemampuan akhir masing-masing kelompok.

Tahap selanjutnya setelah menganalisis pretest penguasaan kompetensi kewarganegaran kelompok eksperiman dan kelompok kontrol adalah melakukan analisis data posttest penguasaan kompetensi kewarganegaran kelompok eksperiman dan kelompok kontrol. Hasil analisis data posttest penguasaaan kompetensi kewarganegaraan kelompok kontrol dan eksperimen dapat dilihat pada tabel 7 .

Tabel 7 Hasil Posttest Penguasaaan Kompetensi Kewarganegaraan Kelompok Kontrol Dan Eksperimen

\begin{tabular}{cccccc}
\hline $\mathbf{N}$ & $\mathbf{t}_{\mathbf{0}}$ & $\mathbf{t}_{\text {tabel }}$ & $\mathbf{d f}$ & $\begin{array}{c}\text { Nilai } \\
\mathbf{P}\end{array}$ & Keterangan \\
\hline 34 & 7,182 & 2,000 & 66 & 0,000 & $<0,05$ \\
\hline
\end{tabular}

Sumber: data hasil penelitian, 2016.

Tabel 7 menunjukkan hasil bahwa terdapat perbedaan yang signifikan tes akhir penguasaan kompetensi kewarganegaraan siswa antara kelompok kontrol dan kelompok eksperimen. Hal ini ditunjukkan hasil to 7,182 lebih besar daripada $t_{\text {tabel }} 2,000$. Pada setiap dimensi kompetensi kewarganegaraan juga menunjukkan hasil sama. Berikut penjabaran 114 setiap dimensi kompetensi kewarganegaraan tabel 8 .

Tabel 8. Rangkuman Hasil Uji-T Posttest Setiap Dimensi Kompetensi

Kewarganegaraan Kelompok Eksperimen dan Kelompok Kontrol

\begin{tabular}{ccccccc}
\hline Data & $\mathbf{N}$ & $\mathbf{t}_{\mathbf{o}}$ & $\mathbf{t}_{\text {tabel }}$ & $\mathbf{d f}$ & Sig. & Ket. \\
\hline $\mathrm{CK}$ & 34 & 6,088 & 2,000 & 66 & 0,000 & $<$ \\
& & & & & & 0,05 \\
$\mathrm{CS}$ & 34 & 2,554 & 2,000 & 66 & 0,013 & $<$ \\
& & & & & & 0,05 \\
$\mathrm{CD}$ & 34 & 2,055 & 2,000 & 66 & 0,044 & $<$ \\
& & & & & & 0,05
\end{tabular}

Ket.: $\mathrm{CK}=$ Civic Knowladge, $\mathrm{CS}=$ Civic Skills, $\mathrm{CD}=$ Civic Disposition

Sumber: data hasil penelitian, 2016.

Tabel 8 menunjukkan hasil bahwa terdapat perbedaan yang signifikan tes akhir pengetahuan kewarganegaraan siswa antara kelompok kontrol dan kelompok eksperimen. Hal ini ditunjukkan $t_{0}$ 6,088 lebih besar daripada $t_{\text {tabel }}$ 2,000. Pada tes akhir keterampilan kewarganegaraan siswa antara kelompok kontrol dan kelompok eksperimen menunjukkan hasil terdapat perbedaan. Hal ini ditunjukkan $t_{0}$ 2,554 lebih besar daripada

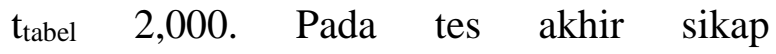
kewarganegaraan siswa antara kelompok kontrol kelompok eksperimen menunjukkan terdapat perbedaan. Hal ini ditunjukkan hasil $t_{0}$ 2,055 lebih besar daripada $t_{\text {tabel }} 2,000$.

Berdasarkan hasil analisis di atas dapat disimpulkan bahwa tes kemampuan akhir penguasaan kompetensi kewarganegaraan dalam pembelajaran PPKn menggunakan model Project citizen dengan pendekatan saintifik menunjukkan terdapat perbedaan dibandingkan dengan model pembelajaran berbasis masalah dengan pendekatan saintifik dalam pembelajaran PPKn di kelas kontrol.

Tahap analisis selanjutnya yaitu dengan menggunakan Gain Score. Perhitungan Gain Score digunakan untuk mengetahui besarnya penguasaan kompetensi kewarganegaraan 
siswa kelas eksperimen dan kelas kontrol. Berikut hasil Gain Score kelompok eksperimen dan kelompok kontrol.

Tabel 9 Hasil Gain Score Penguasaan Kompetensi Kewarganegaraan

\begin{tabular}{lcl}
\hline \multicolumn{1}{c}{ Kelas } & Gain Score & Kategori \\
\hline Eksperimen & 0,38 & sedang \\
Kontrol & 0.15 & rendah \\
\hline
\end{tabular}

Sumber: data hasil penelitian, 2016.

Berdasarkan tabel pengujian gain score skor pretest dan posttest penguasaan kompetensi kewarganegaraan pada tabel 9 . Diketahui skor gain kelompok eksperimen adalah 0,38 dari hasil mean pretest (3.00) dan posttest (3.39). Sementara skor gain pada kelompok kontrol adalah 0,15 dari hasil mean pretest (2.96) dan posttest (3.13). Berikut histogram gain score penguasaan kompetensi kewarganegaraan.

Gambar 5. Histogram Gain Score penguasaan kompetensi kewarganegaraan Perbandingan nilai Gain Score

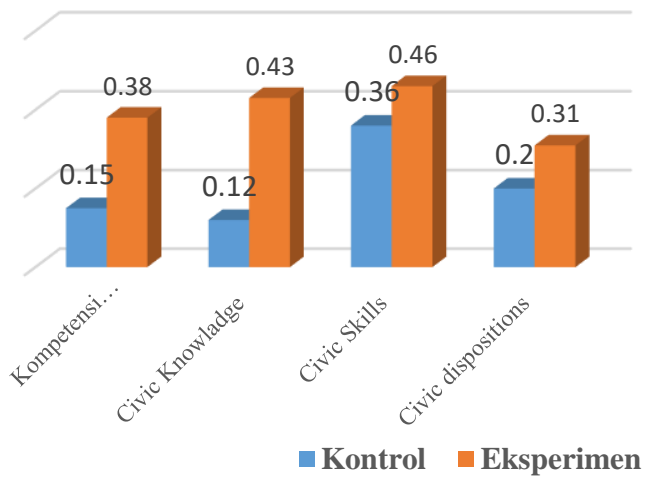

Sumber: data hasil penelitian, 2016.

Disimpulkan bahwa pengaruh kelompok eksperimen yang diberikan perlakuan menggunakan model Project Citizen dengan pendekatan saintifik terhadap penguasaan kompetensi kewarganegaraan dalam pembelajaran PPKn di SMP Negeri 5 Yogyakarta meningkat dalam kategori sedang. Sedangkan, pengaruh kelompok kontrol yang tidak diberikan perlakuan terhadap penguasaan kompetensi kewarganegaraan dalam pembelajaran PPKn di SMP Negeri 5 Yogyakarta meningkat dalam kategori rendah.

Berdasarkan uraian di atas, maka dapat dikatakan terjadinya perbedaan penguasaan kompetensi kewarganegaraan antara siswa yang diajar dengan menggunakan model Project Citizen dengan pendekatan saintifik dengan siswa yang diajar dengan menggunakan pembelajaran konvensional. Jika diperhatikan tahapan dan urutan langkahlangkah pembelajaran kedua model di atas, dapat dilihat bahwa hasil belajar siswa yang diajar dengan model Project Citizen dengan pendekatan saintifik lebih baik bila dibandingkan dengan model pembelajaran konvensional. Dalam proses pembelajaran menggunakan model Project Citizen dengan pendekatan saintifik, guru dapat merangsang siswa untuk berpikir kritis, analitis, reflektif, dan terbuka yang akhirnya mempengaruhi penguasaan kompetensi kewarganegaraan.

Berdasarkan hasil penelitian di atas menunjukkan bahwa penelitian ini menguatkan penelitian sebelumnya yang dilakukan oleh Liou (2004) hasil posttest, menunjukkan bahwa siswa yang berpartisipasi dalam Project citizen signifikan mengungguli siswa di kelompok pembandingg. Penelitian lain yang mendukung adalah penelitian di berbagai negara oleh Craddock et al. (2007) bahwa Project Citizen memberikan dampak/pengaruh bagi pengetahuan, sikap dan keterampilan kewarganegaraan siswa, karena Project Citizen memiliki rancangan yang bersifat generik dan mudah diadaptasi dalam praktik.

Selanjutnya, penelitian Vontz et.al (2000) mengevaluasi efek dari Project citizen pada pengembangan kompetensi kewarganegaraan siswa remaja di Indiana, 
Latvia, dan Lithuania. Hasil yang sama dutunjukkan pengaruh Project citizen dalam membangun kompetensi kewarganegaraan siswa. Penelitian selanjutnya, yang dilakukan oleh Tolo (1998) selama tahun 1996-1997 menemukan bahwa mayoritas siswa dan guru percaya bahwa Project citizen mampu mengembangkan penguasaaan pengetahuan warga negara, keterampilan intelektual dan partisipatif, serta watak warga negara.

Keaktifan dalam pembelajaran menggunakan model prooject citizen sesuai dengan Kurikulum 2013 yang mengedepakan pendekatan saintifik. Keterpaduan model Project citizen dengan pendekatan saintifik mampu mengembangkan penguasan kompetensi kewarganegaraan siswa. Hal ini dikarenakan dalam Kurikulum 2013 telah mengembangkan aspek pengetahuan, sikap dan keterampilan secara utuh. Penilaian dalam Kurikulum 2013 menggunakan penilaian autentik untuk mengukur berbagai dimensi dalam kompetensi kewarganegaraan.

Berdasarkan uraian sebelumnya dapat disimpulkan bahwa penggunaan model project citizen dengan pendekatan saintifik dalam pembelajaran PPKn lebih efektif dibandingkan model pembelajaran berbasis masalah dengan pendekatan saintifik terhadap penguasaan kompetensi kewarganegaraan siswa kelas VIII SMP Negeri 5 Yogyakarta. Selain itu, terdapat perbedaan yang positif dan signifikan penguasaan kompetensi kewarganegaraan dalam pembelajaran PPKn mengunakan model project citizen dengan pendekatan saintifik dibandingkan model pembelajaran berbasis masalah dengan pendekatan saintifik pada siswa kelas VIII SMP Negeri 5 Yogyakarta. Oleh karena itu, guru mata pelajaran PPKn perlu menerapkan model pembelajaran tersebut agar hasil belajar siswa lebih optimal.

\section{Simpulan}

Berdasarkan hasil analisis dan pembahasan yang dilakukan pada bab sebelumnya, maka dapat disimpulkan demikian. Pertama, Hasil penelitian menunjukkan bahwa terdapat pengaruh yang signifikan penerapan model Project Citizen dengan pendekatan saintifik dalam pembelajaran PPKn terhadap penguasaan kompetensi kewarganegaraan dibandingkan dengan menggunakan model pembelajaran berbasis masalah dengan pendekatan saintifik. Hal ini ditunjukkan hasil posttest kelompok kontrol dan eksperimen to 7,182> ttabel 2,000. Pada setiap dimensi kompetensi kewarganegaraan juga menunjukkan hasil terdapat perbedaan yang signifikan, yaitu: pengetahuan kewarganegaraan (to 6,088 > ttabel 2,000), keterampilan kewarganegaraan (to 2,554> ttabel 2,000), sikap kewarganegaraan (to 2,055> ttabel 2,000).

Kedua, analisis gain score menunjukkan pengaruh model Project Citizen dengan pendekatan saintifik dalam pembelajaran PPKn terhadap penguasaan kompetensi kewarganegaraan siswa kelas VIII SMP Negeri 5 Yogyakarta dalam kategori sedang $(0,38)$. Sedangkan pengaruh model pembelajaran berbasis masalah dalam pembelajaran PPKn terhadap penguasaan kompetensi kewarganegaraan siswa kelas VIII SMP Negeri 5 Yogyakarta dalam kategori rendah $(0,15)$.

Berdasarkan penelitian yang dilakukan, ditemukan pengaruh yang signifikan antara penggunaan model Project Citizen dengan pendekatan saintifik dalam pembelajaran PPKn terhadap Penguasaan kompetensi kewarganegaraan siswa kelas VIII SMP Negeri 5 Yogyakarta. Model Project Citizen dengan pendekatan saintifik sebagai suatu inovasi pembelajaran yang dapat 
mengembangkan potensi dan kebutuhan belajar siswa, melatih kerja sama, keberanian, percaya diri dan mampu bersosialisasi banyak orang. Selain itu, pembelajaran PPKn mampu menjadi wahana siswa dalam belajar berinteraksi langsung dengan para pembuat kebijakan publik.

Berdasarkan simpulan dan implikasi di atas, dapat disajikan beberapa saran sebagai berikut 1) Guru dapat memanfaatkan penelitian ini untuk menambah pengetahuan dan memberikan inspirasi tentang model tertentu dalam pembelajaran, khususnya penguasaan kompetensi kewarganegaraan dalam pembelajaran PPKn. 2) Siswa dapat memanfaatkan penelitian ini untuk memacu penguasaan kompetensi kewarganegaraan siswa menjadi lebih aktif dan termotivasi dalam pembelajaran PPKn. 3) Pihak sekolah dapat memanfaatkan penelitian ini untuk meningkatkan kualitas pembelajaran PPKn, khususnya penguasaan kompetensi kewarganegaraan. 4) Pada penelitian ini, hubungan sinergis antara peneliti, guru, dan siswa perlu dilakukan demi pengaruh penelitian pembelajaran.

\section{Daftar Pustaka}

Alawiyah, F. (2015). Penghentian sementara kurikulum 2013. Studi Pendidikan Pada Bidang Kesejahteraan Sosial, Pusat Pengkajian Pengolahan Data Dan Informasi (P3DI) Sekretariat Jenderal DPR RI, VII(2), 9-12.

Audigier, F. (2000). Basic concepts and core competencies for education for democratic citizenship. Strasbourg: Council of Europe.

Center for Civic Education. (2006). We the people... project citizen. Calabasas, CA: Center for Civic Education.

Cogan, J. J. (1998). Citizenship Education for the 21st Century: Setting the Context. In J. J. Cogan \& R. Derricott (Eds.), Citizenship for the 21 st Century: An
Introduction Perspectives on Education (pp. 1-20).

Craddock, A., Fischer, J., \& Subreenduth, S. (2007). Research report: Teaching for democracy. Assessing project citizen in poland, south africa, ukraine and the united states. Ohio: International Democratic Education Institute. http://doi.org/10.4324/9780203765081

Doğanay, A. (2012). A curriculum framework for active democratic citizenship education. In M. Print \& D. Lange (Eds.), Schools, Curriculum and Civic Education for Building Democratic Citizens (pp. 19-39). Roterdam, Boston, Taipe: Sense Publisher.

Fraillon, J., Schulz, W., \& Ainley, J. (2012). ICCS 2009 Asian report: Civic knowledge and attitudes among lowersecondary students in five Asian countries. (J. Fraillon, W. Schulz, \& J. Ainley, Eds.), International Association for the Evaluation of Educational Achievement (IEA) All. Amsterdam: International Association for the Evaluation of Educational Achievement (IEA). Retrieved from http://search.ebscohost.com/login.aspx? direct $=$ true $\& d b=$ eric $\& A N=E D 544595 \&$ site $=$ ehost-live

Himmelmann, G. (2013). Competences for teaching, learning and living democratic citizenship. In M. Print \& D. Lange (Eds.), Civic Education and Competences for Engaging Citizens in Democracies (pp. 3-7). Roterdam, Boston, Taipe: Sense Publishers.

Joyce, B., Weil, M., \& Calhoun, E. (2000). Model of teaching. New York: Allyn and bacon a Pearson Education Company.

Kerr, D. (1999). Citizenship education : An international comparison. London: National Foundation for Educational Research-NFER.

Kintisch, S., \& Cordero, W. (1993). Breaking away from the textbook: a new approach to teaching American history. Lancaster, PA: Technomic Publishing Company, 
Inc.

Liou, S.-M. (2004). The effect of we the people... Project citizen on the civic skills and dispositions of Taiwanese senior high school students. 師大學報: 教育類 (Journal of Taiwan Normal University. Education ), 49(1), 63-89.

Nancy, H. (2001). Using we the people.... programs in social studies teacher education. In J. J. Patrick \& R. S. Leming (Eds.), Principles and practices of democracy in the education of social studies teachers (pp. 167-184). Bloomington: ERIC Clearinghouse for Social Studies/Social Science Education, ERIC Clearinghouse for International Civic Education, and Civitas.

Patrick, J. J., \& Vontz, T. S. (2001). Component of Education for Democratic Citizenship in the Preparation of Social Studies Teachers. In J. J. Patrick \& Roberts S Leming (Eds.), Principles and Practices of Democracy in the Education of Social Studies teachers. Civic Learning in Teacher Education (Vol. 1, pp. 39-53). Bloomington IN: ERIC Clearinghouse for Social Studies/Social Science Education.

Print, M. (2013). Competencies for democratic citizenship in europe. In M. Print \& D. Lange (Eds.), Civic Education and Competences for Engaging Citizens in Democracies (pp. 37-50). Roterdam, Boston, Taipe: Sense Publishers.

Print, M., \& Lange, D. (Eds.). (2012). Schools, curriculum and civic education for building democratic citizens. Roterdam, Boston, Taipe: Sense Publishers. http://doi.org/10.1007/978-
94-6209-167-2

Pusat Kurikulum Balitbang Depdiknas. (2007). Naskah akademik kajian kebijakan kurikulum Pendidikan Kewarganegaraan. Jakarta: Pusat Kurikulum Balitbang Depdiknas.

Samsuri. (2011). Model pembelajaran Pendidikan Kewarganegaraan untuk membangun komperensi warga negara. In Kuliah Umum di Program Studi Pendidikan Pancasila dan Kewarganegaraan (PPKn) FKIP Universitas Ahmad Dahlan 9 Mei 2011 (pp. 1-13). Yogyakrta.

Samsuri. (2013). Paradigma pendidikan kewarganegaraan dalam kurikulum 2013, (September), 1-11.

Tolo, K. W. (1998). An assessment of we the people...project citizen: promoting citizenship in classrooms and communities. Austin: Lyndon B. School of Public Affairs, The University of Texas Austin.

Vontz, T. S., Metcalf, K. K., \& Patrick, J. J. (2000). "Project Citizen" and the civic development of adolescent students in Indiana, Latvia, and Lithuania. Bloomington IN: ERIC Clearinghouse for Social Studies.

Vontz, T. S., \& Nixon, W. A. (1999). Reconsidering issue-centered civic education among early adolescents: Project Citizen in the United States and abroad. In Principles and practices of education for democratic citizenship: International perspectives and projects. Bloomington: IN: ERIC Adjunct Clearinghouse for International Civic Education. 